\title{
EVIDENCE OF A NORTH ATLANTIC RIGHT WHALE CALF (EUBALAENA GLACIALIS) BORN IN NORTHEASTERN U.S. WATERS
}

\author{
Melissa R. Patrician \\ Woods Hole Oceanographic Institution \\ Biology Department, M.S. \#32 \\ Woods Hole, MA 02543, USA \\ E-mail: mpatrician@whoi.edu \\ Ingrid S. Biedron \\ Bioacoustics Research Program \\ Cornell Laboratory of Ornithology \\ 159 Sapsucker Woods Road \\ Ithaca, NY 14850, USA \\ H. Carter Esch \\ Woods Hole Oceanographic Institution \\ Biology Department, M.S. \#33 \\ Woods Hole, MA 02543, USA \\ Frederick W. Wenzel \\ National Marine Fisheries Service \\ Northeast Fisheries Science Center \\ 166 Water Street \\ Woods Hole, MA 02543, USA \\ Lindsay A. Cooper \\ New England Aquarium \\ Central Wharf \\ Boston, MA 02110, USA \\ Philip K. Hamilton \\ New England Aquarium \\ Central Wharf \\ Boston, MA 02110, USA \\ Allison H. Glass \\ National Marine Fisheries Service \\ Northeast Fisheries Science Center \\ 166 Water Street \\ Woods Hole, MA 02543, USA \\ Mark F. Baumgartner \\ Woods Hole Oceanographic Institution \\ Biology Department, M.S. \#33 \\ Woods Hole, MA 02543, USA
}


The general temporal and geographical patterns of North Atlantic right whale

2 (Eubalaena glacialis) calving events have been clarified during the last quarter century of

3 research (Kraus and Rolland 2007). Right whales give birth to a single calf every three to

4 five years after a twelve- to thirteen-month gestation period (Best 1994; Kraus and Hatch

5 2001). Most calves are born between December and March in the coastal waters of the

6 southeastern U.S., the only known calving ground for this species (Fig. 1) (Kraus et al.

7 2007; Winn et al. 1986). Although historical whaling records suggest that there were

8 once two winter calving grounds, one off the southeastern U.S. and the other off

9 northwestern Africa, it appears that only the former is still used today (Notarbartolo di

10 Sciara et al. 1998; Reeves and Mitchell 1986; 1988). In the late winter, right whales

11 leave the calving grounds and migrate to their foraging grounds off the northeastern U.S.

12 and Canadian Maritimes (Fig. 1). North Atlantic right whales can be found in Cape Cod

13 and Massachusetts Bays throughout the late winter and early spring (Hamilton and Mayo

14 1990; Mayo and Marx 1990; Schevill et al. 1986), in the Great South Channel during

15 mid-spring to early summer (Kenney et al. 1995), and in the Bay of Fundy (Kraus et al.

16 1982) and on the Scotian Shelf (Mitchell et al. 1986; Stone et al. 1988) during the

17 summer and fall. Some individuals (mostly pregnant females and juveniles) return to the

18 calving grounds off the southeastern U.S. in December and January, but the location of

19 the rest of the population during those months is currently unknown (although recent

20 evidence suggests that right whales are present in the Gulf of Maine and on the Scotian

21 Shelf throughout the winter (Mellinger et al. 2007; T. Cole pers comm. ${ }^{1}$; S. Van Parijs

22 pers comm. ${ }^{2}$ ).

\footnotetext{
${ }^{1}$ Tim V.N. Cole, National Marine Fisheries Service, Northeast Fisheries Science Center, 166 Water Street, Woods Hole, MA 02543, USA. February 2008.
} 
These seasonal movements describe the typical distribution of the population, but

24 there is a great deal of variability in habitat use among individuals. Adult females are

25 seen less often in the foraging habitats described above than males and juveniles (Brown

26 et al. 2001). The lower Bay of Fundy is the most common nursing ground for calves in

27 the summer and fall; however, there are some mothers (referred to as "non-Fundy"

28 animals) who do not visit the Bay of Fundy with their calves (Schaeff et al. 1993).

29 There are additional documented habitat areas used by right whales, including Jeffrey’s

30 Ledge (Weinrich et al. 2000), the central Gulf of Maine (Waring et al. 2006), and the

31 central Scotian Shelf (Mitchell et al. 1986). There have been opportunistic sightings of

32 right whales in the Gulf of Mexico, northwestern Gulf of St. Lawrence, eastern and

33 southern Newfoundland, southern Greenland, Iceland, and northern Norway (IWC 2001;

34 Knowlton et al. 1992; Lien et al. 1989). These seemingly anomalous sightings appear to

35 occur largely on alternative foraging grounds (except the Gulf of Mexico sightings),

36 although there has been little documentation of alternative habitats used for calving.

37 Right whales are individually identified using scars on their bodies (Kraus 1990)

38 and the pattern of callosity tissue on their head (Kraus et al. 1986; Payne et al. 1983).

39 Callosities are areas of cornified skin that grow on the head, behind the blowholes, above

40 the eyes, on the chin and along the mandibles. The callosities are infested with cyamids

41 which are light in color and help to highlight the patches of callosity (Hamilton et al.

42 2007). The pattern of these growths are stable over time and photographs of right whale

43 heads have been used to develop a detailed database of identified individuals, the North

44 Atlantic Right Whale Catalog, in which each individual is assigned a unique

2 Sophie M. Van Parijs, National Marine Fisheries Service, Northeast Fisheries Science Center, 166 Water Street, Woods Hole, MA 02543, USA. February 2008. 
45 identification number (Eg \#XXXX) (Hamilton et al. 2007). Calves are born without any

46 callosity and it can be several months before it begins to develop; the callosity is

47 generally not fully developed until the late summer or fall of the birth year. Calves are

48 also born with a prominent dip in their rostrum, forward of the blowholes, due to their

49 undeveloped head. This dip becomes less apparent as they grow during their first year

50 (Hamilton et al. 2007; Sironi 2005).

51 On 2 June 2007 at 17:00 GMT, a North Atlantic right whale was observed with a

52 small calf in the Great South Channel $\left(41.60^{\circ} \mathrm{N}, 68.79^{\circ} \mathrm{W}\right)$ from the NOAA Ship

53 Albatross IV during a right whale foraging ecology cruise (Fig. 1). The mother/calf pair

54 passed within $500 \mathrm{~m}$ of the vessel and was photographed (Fig. 2) with Nikon D50 and

55 D70 digital cameras outfitted with 70-300 $\mathrm{mm}$ telescopic lenses. The adult was identified

56 as Eg \#2360, a reproductively active female that had previously given birth to one other

57 calf, Eg \#3460 ${ }^{3}$. The calf observed on 2 June (later designated Eg \#3760) was

58 approximately $6 \mathrm{~m}$ in length and was observed swimming in the nursing position next to

59 the mother. It had a small undeveloped head and no visible callosity tissue or cyamids

60 (although only a portion of the head was visible in the photographs). While this length

61 approximation is our best estimate, we recognize that there are likely large error bounds

62 with this estimate, due to the distance from which we were viewing the animals. Given

63 the time of year of this sighting, it was expected that this calf would have been

64 approximately 3 to 6 months of age; however, its size, head shape, lack of callosity and

65 lack of cyamids suggest that it was much younger. Based on necropsy reports, newborn

66 North Atlantic right whale calves are estimated to be between 4.0 and $5.5 \mathrm{~m}$ in length

\footnotetext{
${ }^{3}$ North Atlantic Right Whale Consortium Identification Database, New England Aquarium, Central Wharf, Boston, MA, 02110, USA. June 2007.
} 
67 (Kraus et al. 1986; Moore et al. 2004), and Moore et al. 2004 estimated a $7.7 \mathrm{~m}$ long

68 ship-struck calf to be 3-4 months old. These length estimates suggest that the calf we

69 observed was quite young at the time of sighting. At the time of our sighting, the calf

70 appeared to have grooves across its back (Fig. 2b) reminiscent of fetal folds found in

71 newborn calves (folding of the skin caused by the calf's position in the womb). These

72 grooves are similar to the fetal folds observed by Bonde (2004) on a stranded right whale

73 calf that was one week old. Bottlenose dolphins and gray whales display fetal folds that

74 are only visible on newborn calves and disappear quickly once a calf starts nursing

75 (Barco et al. 1999; Eberhardt and Norris 1964; Sumich and Harvey 1986).

76 Eg \#2360 was encountered in 2007 prior to our 2 June sighting by the NOAA

77 Northeast Fisheries Science Center right whale aerial survey team. The aerial survey

78 team observed Eg \#2360 without a calf on 30 March $2007\left(41.57^{\circ} \mathrm{N}, 69.37^{\circ} \mathrm{W}\right)$ and 26

79 April $2007\left(41.27^{\circ} \mathrm{N}, 68.87^{\circ} \mathrm{W}\right), 48$ and $37 \mathrm{~km}$ from our 2 June sighting, respectively

80 (Fig. 1). On each occasion, the airplane circled for approximately five minutes to obtain

81 identification photographs; it is unlikely that an accompanying calf would have been

82 missed by the three experienced aerial survey observers and the pilots. As newborn

83 calves have never been seen separated from their mothers (M. Zani pers comm. ${ }^{4}$ ), Eg

$84 \quad$ \#2360 must have given birth after 26 April making the calf no older than 37 days when

85 first sighted.

86 To further determine an estimated maximum age of Eg \#3760 on 2 June, a subset

87 of calves whose date of birth could be narrowed to less than two weeks were reviewed

88 (Fig. 3a \& 3b). The development of callosity growth and cyamids colonization were

89 analyzed for these calves. In all cases, cyamids first appeared on the margins of the lip

\footnotetext{
${ }^{4}$ Monica Zani, New England Aquarium, Central Wharf, Boston, MA 02110, USA. March 2008.
} 
90 within six to fifteen days of birth. Although Eg \#3760's head was not fully visible in the

912 June sighting, the right lip margin was visible in one image (Fig. 3c) and no cyamids

92 were present. This suggests it was likely less than two weeks of age. The photographs of

93 Eg \#3760 on 2 June were also compared to calves of known age (5-6 months) in the

94 Great South Channel (Fig. 3d \& 3e). From this comparison, it is clear that the head of Eg

$95 \quad \# 3760$ is much less developed and has less callosity and cyamid coverage than expected

96 of a 5-6 month old calf in the Great South Channel.

97 According to R. Leaper (pers comm. ${ }^{5}$ ), based on modeling sighting patterns of

98 individually identified whales, it takes approximately 19 days for an adult right whale to

99 travel from the southeastern U.S. calving grounds to the northern feeding grounds,

100 suggesting an average swim speed of 1.8 knots. Firestone et al. (2008) suggest that it

101 takes a right whale 21-24 days to make this same one-way trip. During August 2000, Eg

102 \#2320 was tagged with a satellite transmitter in the Bay of Fundy and later traveled from

103 the Great South Channel to the coast of Georgia in 19 days (Baumgartner and Mate

104 2005). Because Eg \#3760 could be no older than 37 days, and was likely less than 15

105 days old, we consider it highly unlikely that Eg \#2360 could have traveled to the

106 southeastern U.S. calving grounds after she was seen on 26 April to give birth and then

107 return to the Great South Channel before being sighted on 2 June. While we cannot

108 determine the exact location of the calving event given our observations, it is conceivable

109 that Eg \#2360 made a partial southward migration to the mid-Atlantic region (to a

110 location between New Jersey and the Carolinas) to give birth. In the past, mother/calf

111 pairs have been seen in the mid-Atlantic region without being seen in the southeastern

\footnotetext{
${ }^{5}$ Russell Leaper, International Fund for Animal Welfare, England. December 2007.
} 
112 U.S. during the same year, suggesting that calving may have occurred in this area before ${ }^{6}$

113 . This scenario would still require a relatively quick journey of several hundreds of

114 kilometers with a newborn calf. As most calves remain in the southeast for weeks to

115 months after their birth (M.Zani, pers. comm. ${ }^{7}$ ), it is slightly more plausible that the calf

116 was born in waters off the northeastern U.S., possibly off the coast of New England.

117 Interestingly, Eg \#2360 and her calf did eventually visit the southeastern U.S.

118 calving grounds 1.5 months after she was seen in the Great South Channel. On 17 July

119 2007, the mother/calf pair was photographed off the northeast coast of Florida (30.28 ${ }^{\circ} \mathrm{N}$,

$12081.23^{\circ} \mathrm{W}$ ) by a fishing vessel, six months after the peak time for mothers and calves in

121 the area (Fig. 1). This is the first sighting of a North Atlantic right whale in the

122 southeastern U.S. during the summer ${ }^{8}$. However, this is not the first anomalous sighting

123 of Eg \#2360. In April 2004, she brought her first calf (Eg \#3460, born in the southeastern

124 U.S. in January 2004) into the Gulf of Mexico, a very rare event (Kenney 2007). Eg

125 \#3760 (the second calf of Eg \#2360) was easily identifiable in July 2007 and in

126 subsequent sightings because of strange growths that resembled callosities on the

127 animal's back and right flank (Fig. 4). These growths look like callosity tissue in their

128 color, topography, texture and temporal durability. They were first documented in the

129 July 2007 sighting by the Marine Resource Council and were observed again by the New

130 England Aquarium (Bay of Fundy; September 2007) and by Wildlife Trust (southeastern

131 U.S.; December 2007) (Fig. 1). None of the 510 cataloged right whales have callosity

132 tissue on their backs, nor has this condition been described in the other two right whale

\footnotetext{
${ }^{6}$ North Atlantic Right Whale Consortium Identification Database, New England Aquarium,Central Wharf, Boston, MA, 02110, USA. April 2008.

${ }^{7}$ Monica Zani, New England Aquarium, Central Wharf, Boston, MA 02110, USA. August 2008.

${ }^{8}$ North Atlantic Right Whale Consortium Identification Database, New England Aquarium,Central Wharf, Boston, MA, 02110, USA. December 2007.
} 
133 species, E. australis or E. japonica. The only comparable non-callosity growths that

134 have been documented on right whales are the craterous eruptions described by Hamilton

135 and Marx (2005). These lesions showed a developmental progression over several

136 months, were rimmed by a raised crater, and were not infested with cyamids. The

137 growths on Eg \#3760, however, were present for the 5-month sighting history from July

138 to December 2007, are not bordered by a raised rim, and show a similar cyamid

139 infestation pattern to the callosities found on the head. These growths have not been

140 biopsied, and as a result, their composition is still unknown.

141 Since the beginning of aerial surveys in the calving grounds of the southeastern

142 U.S. (1994), six other North Atlantic right whale mother/calf pairs have been observed in

143 the waters near the northeastern U.S. and Canada during the spring or summer without

144 being seen in the southeastern U.S. during the preceding winter (Table 1). Until now, it

145 had been assumed that these calves sighted only in waters in the northeast were all calves

146 that were present but overlooked during the surveys in the southeastern U.S during the

147 calving season. However, our recent observations provide a case for re-evaluating those

148 data collected previously.

149 In order to estimate the age of the other six calves not seen in the southeast U.S.,

150 as well as compare Eg \#3760 to other calves, a baseline approximation of head size, head

151 shape (using dip in rostrum), and callosity formation for calves seen during the winter

152 calving season, spring and summer was developed using a large suite of photographs of

153 many calves in the North Atlantic Right Whale Catalog. Photos of all seven calves were

154 compared to the baseline images using the above three parameters. Analysis showed that

155 the parameters for five of the seven calves were as expected for the time of year they 
156 were seen, indicating that, while not observed on the calving ground, they were likely

157 born during the known December to March calving time. Eg \#3760 and Eg \#3145 (2001

158 calf of \#2145), first seen in early May, had much smaller heads with a prominent dip in

159 the rostrum and less callosity formation compared to the baselines images of calves seen

160 during the spring. These two calves looked more like the baseline photos from winter.

161 To further compare these two calves with other calves, images were reviewed for calves

162 specifically seen in the southeastern U.S. and seen subsequently in the Bay of Fundy

163 (making them approximately 8-9 months old). Both Eg \#3760 and Eg \#3145 had less

164 callosity development and a smaller head with a larger dip in the rostrum than the calves

165 known to be 8-9 months old (Fig. 5) and looked more like calves from the springtime

166 baseline images. While a time frame for the birth of Eg \#3145 cannot be identified as it

167 can for Eg \#3760, it is possible that Eg \#3145 was also a calf born outside of the

168 southeastern U.S., and later in the year, but went unnoticed until now.

169 Our observations suggest that there may be a northern calving ground that is

170 utilized by certain animals. There are historic reports which support the contention of

171 calving outside of the southeastern U.S. Cape Cod Bay has been hypothesized in the past

172 to be an alternative calving ground; during 24 years of observations, Watkins and

173 Schevill (1982) and Schevill et al. (1986) inferred that at least two calves had been born

174 in the Bay, since adults were seen without calves and then re-sighted within a week with

175 extremely small calves. However, there were no photographic data of the females before

176 and after to confirm these observations. Payne (1995) suggests that there are striking

177 geographic similarities between Cape Cod Bay and Península Valdés, Argentina, one of

178 the calving grounds for southern right whales: they are both at the same latitude (in 
179 opposite hemispheres); Peninsula Valdés and Cape Cod Bay and the islands are the same

180 size; and both are virtually landlocked bays. Kenney (2002) suggested that Delaware

181 Bay in the mid-Atlantic region might once have been a calving ground for North Atlantic

182 right whales as well. According to historical whaling records, Delaware Bay was once an

183 area of whaling activity which peaked during the winter, the same time of year during

184 which North Atlantic right whales currently use the southeastern U.S. calving grounds

185 (Reeves et al. 1999; Reeves et al. 1978).

186 It is unclear how frequently calving events occur outside the southeast U.S., but it

187 appears from our observations and those of Watkins and Schevill (1982) and Schevill et

188 al. (1986) that calving in northeastern U.S. waters is at least possible. According to data

189 collected between 1980 and 1992, 25\% of all reproductively active North Atlantic right

190 whale females had never been seen in the southeastern U.S. calving grounds (Brown et

191 al. 2001), suggesting that calving may consistently occur elsewhere. However, Brown et

192 al.'s analysis may have been affected by the low survey effort in the southeast U.S. prior

193 to the mid 1990 's. Photo-identification to monitor the right whale population currently

194 takes place primarily in the southeastern U.S. in the winter and known northern foraging

195 habitats in the spring and summer. However, if right whales are calving in northern

196 waters outside of these known habitats, then an undetermined fraction of annual right

197 whale reproduction may be unaccounted for. Moreover, improved monitoring and

198 management of habitats, particularly offshore habitats like the Great South Channel, may

199 be warranted during late winter and spring. Reproductively active females, including

200 pregnant females and females accompanied by calves, spend more time at the surface,

201 and therefore, may be at greater risk of ship strikes than the rest of the population 
202 (Baumgartner and Mate 2003). It is important to improve the understanding of right

203 whale spatial and temporal use of alternative calving habitats in order to most effectively

204 manage ship traffic and commercial fishing in these areas.

205

206

207

ACKNOWLEDGEMENTS

208

209 We thank Tim Cole, Jeremy Firestone, Timothy Frasier, Robert Kenney, Amy Knowlton,

210 Scott Kraus, Russell Leaper, William McLellan, Michael Moore, Patricia Naessig, Sofie

211 Van Parijs, Monica Zani, and the two anonymous reviewers of this manuscript for

212 interesting and useful discussions and critiques. Also, we thank the officers, crew, and

213 scientific staff of the NOAA Ship Albatross IV. 


\section{LITERATURE CITED}

Barco, S.G., W.M. Swingle, W.A. McLellan, R.N. Harris and D.A. Pabst. 1999. Local abundance and distribution of bottlenose dolphins (Tursiops truncatus) in the nearshore waters of Virginia Beach, Virginia. Marine Mammal Science 15:394-408.

Baumgartner, M.F. and B.R. Mate. 2003. Summertime foraging ecology of North Atlantic right whales. Marine Ecology Progress Series 264:123-135.

Baumgartner, M.F. and B.R. Mate. 2005. Summer and fall habitat of North Atlantic right whales (Eubalaena glacialis) inferred from satellite telemetry. Canadian Journal of Fisheries \& Aquatic Sciences 62:527-543.

Best, P.B. 1994. Seasonality of reproduction and the length of gestation in southern right whales Eubalaena australis. Journal of Zoology: Proceedings of the Zoological Society of London 232:175-189.

Bonde, R.K. 2004. RKB-1457 (Eubalaena glacialis): Necropsy examination report. U.S. Geological Survey.

Brown, M.W., S. Brault, P.K. Hamilton, R.D. Kenney, A.R. Knowlton, M.K. Marx, C.A. Mayo, C.K. Slay and S.D. Kraus. 2001. Sighting heterogeneity of right whales in the western North Atlantic: 1980-1992. Journal of Cetacean Research and Management (Special Issue) 2:245-250.

Eberhardt, R.L. and K.S. Norris. 1964. Observations of newborn pacific gray whales on mexican calving grounds. Journal of Mammalogy 45:88-95.

Firestone, J., S.B. Lyons, C. Wang and J.J. Corbett. 2008. Statistical modeling of North Atlantic right whale migration along the mid-Atlantic region of the eastern seaboard of the United States. Biological Conservation 141:221-232.

Hamilton, P.K., A.R. Knowlton and M.K. Marx. 2007. Right whales tell their own stories: The photo-identification catalog. Pages 75-104 in S.D. Kraus and R.M. Rolland, eds. The Urban Whale: North Atlantic Right Whales at the Crossroads. Harvard University Press, Cambridge, Massachusetts.

Hamilton, P.K. and C.A. Mayo. 1990. Population characteristics of right whales (Eubalaena glacialis) observed in Cape Cod and Massachusetts Bays, 1978-1986. Report of the International Whaling Commission (Special Issue 12):203-208.

Hamilton, P.K. and M.K. Marx. 2005. Skin lesions on North Atlantic right whales: categories, prevalence and change in occurrence in the 1990s. Diseases of Aquatic Organisms 68:71-82. 
IWC (International Whaling Commission). 2001. Report of the workshop on status and trends of western North Atlantic right whales. Journal of Cetacean Research \& Management Special Issue 2:61-87.

Kenney, R.D. 2002. North Atlantic, North Pacific and Southern Right Whales. Pages 806-813 in W.F. Perrin, B. Wursig and J.G.M. Thewissen, eds. The Encyclopedia of Marine Mammals. Academic Press, San Diego, California.

Kenney, R.D. 2007. Right Whales and Climate Change: Facing the Prospect of a Greenhouse Future. Pages 436-459 in S.D. Kraus and R.M. Rolland, eds. The Urban Whale: North Atlantic Right Whales at the Crossroads. Harvard University Press, Cambridge, Massachusetts.

Kenney, R.D., H.E. Winn and M.C. Macaulay. 1995. Cetaceans in the Great South Channel, 1979-1989: right whale (Eubalaena glacialis). Continental Shelf Research 15:385-414.

Knowlton, A.R., J. Sigurjósson, J.N. Ciano and S.D. Kraus. 1992. Long-distance movements of North Atlantic right whales (Eubalaena glacialis). Marine Mammal Science 8:397-405.

Kraus, S.D. 1990. Rates and potential causes of mortality in North Atlantic right whales (Eubalaena glacialis). Marine Mammal Science 6:278-291.

Kraus, S.D. and J.J. Hatch. 2001. Mating strategies in the North Atlantic right whale (Eubalaena glacialis). Journal of Cetacean Research and Management (Special Issue) 2:237-244.

Kraus, S.D., R.M. Pace III and T.R. Frasier. 2007. High Investment, Low Return: The Strange Case of Reproduction in Eubalaena Glacialis. Pages 172-199 in S.D. Kraus and R.M. Rolland, eds. The Urban Whale: North Atlantic Right Whales at the Crossroads. Harvard University Press, Cambridge, Massachusetts.

Kraus, S.D., J.H. Prescott, A.R. Knowlton and G.S. Stone. 1986. Migration and calving of right whales (Eubalaena glacialis) in the western North Atlantic. Report of the International Whaling Commission (Special Issue) 10:139-144.

Kraus, S.D., J.H. Prescott, P.V. Turnbull and R.R. Reeves. 1982. Preliminary notes on the occurence of the North Atlantic right whale (Eubalaena glacialis) in the Bay of Fundy. Report of the International Whaling Commission 32:407-411.

Kraus, S.D. and R.M. Rolland. 2007. Right Whales in the Urban Ocean. Pages 1 - 38 in S. Kraus and R.M. Rolland, eds. The Urban Whale: North Atlantic Right Whales at the Crossroads. Harvard University Press, Cambridge, Massachusetts. 
Lien, J., R. Sears, G.B. Stenson, P.W. Jones and I.-H. Ni. 1989. Right whale, Eubalaena glacialis, sightings in waters off Newfoundland and Labrador and the Gulf of St. Lawrence, 1978-1987. Canadian Field-Naturalist 103:91-93.

Mayo, C.A. and M.K. Marx. 1990. Surface foraging behavior of the North Atlantic right whale and associated plankton characteristics. Canadian Journal of Zoology 68:22142220.

Mellinger, D.K., S.L. Nieukirk, H. Matsumoto, S.L. Heimlich, R.P. Dziak, J. Haxel and M. Fowler. 2007. Seasonal occurrence of North Atlantic right whale (Eubalaena glacialis) vocalizations at two sites on the Scotian Shelf. Marine Mammal Science 23:856-867.

Mitchell, E., V.M. Kozicki and R.R. Reeves. 1986. Sightings of right whales, Eubalaena glacialis, on the Scotian Shelf, 1966-1972. Report of the International Whaling Commission (Special Issue) 10:83-107.

Moore, M.J., A.R. Knowlton, S.D. Kraus, W.A. McLellan and K. Bonde Robert. 2004. Morphometry, gross morphology and available histopathology in North Atlantic right whale (Eubalaena glacialis) mortalities (1970-2002). Journal of Cetacean Research and Management 6:199-214.

Notarbartolo di Sciara, G., E. Politi, A. Bayed, P.C. Beaubrun and A.R. Knowlton. 1998. A winter cetacean survey off southern Morocco, with a special emphasis on right whales. Report of the International Whaling Commission 48:547-550.

Payne, R. 1995. Among Whales. Charles Scribner's Sons, New York, New York.

Payne, R., O. Brazier, E.M. Dorsey, J.S. Perkins, V.J. Rowntree and A. Titus. 1983. External features in southern right whales (Eubalaena australis) and their use in identifying individuals. Pages 371-445 in R. Payne, ed. Communication and Behavior of Whales. Westview Press, Colorado.

Reeves, R.R., J.M. Breiwick and E.D. Mitchell. 1999. History of whaling and estimated kill of right whales, Balaena glacialis, in the northeastern United States, 1620-1924. Marine Fisheries Review 61:1-36.

Reeves, R.R., J.G. Mead and S. Katona. 1978. The right whale, Eubalaena glacialis, in the western North Atlantic. Report of the International Whaling Commission 28:303-312.

Reeves, R.R. and E. Mitchell. 1986. American pelagic whaling for right whales in the North Atlantic. Report of the International Whaling Commission (Special Issue) 10:221254.

Reeves, R.R. and E. Mitchell. 1988. History of whaling in and near North Carolina. NOAA Technical Report NMFS 65:1-28. 
Schaeff, C.M., S.D. Kraus, M.W. Brown and B.N. White. 1993. Assessment of the population structure of western North Atlantic right whales (Eubalaena glacialis) based on sighting and mtDNA data. Canadian Journal of Zoology 71:339-345.

Schevill, W.E., W.A. Watkins and K.E. Moore. 1986. Status of Eubalaena glacialis off Cape Cod. Report of the International Whaling Commission (Special Issue) 10:79-82.

Sironi, M., S.D. Kraus, E.V. Nordheim, V.J. Rowntree and C.T. Snowdon. 2005. Age estimation of North Atlantic right whales (Eubalaena glacialis) by allometric measurements on photographs. Paper SC/57/BRG7 presented to the International Whaling Commission Scientific Committee, June 2005. 14pp.

Stone, G.S., S.D. Kraus, J.H. Prescott and K.W. Hazard. 1988. Significant aggregations of the endangered right whale, Eubalaena glacialis, on the continental shelf of Nova Scotia. Canadian Field-Naturalist 102:471-474.

Sumich, J.L. and J.T. Harvey. 1986. Juvenile mortality in gray whales (Eschrichtius robustus). Journal of Mammalogy 67:179-182.

Waring, G., E. Josephson, C.P. Fairfield and K. Maze-Foley. 2006. U. S. Atlantic and Gulf of Mexico Marine Mammal Stock Assessments - 2006. NOAA Technical Memorandum NMFS-NE-201, 378 pp. National Marine Fisheries Service, Woods Hole, Massachusetts.

Watkins, W.A. and W.E. Schevill. 1982. Observations of right whales, Eubalaena glacialis, in Cape Cod waters. Fishery Bulletin 80:875-880.

Weinrich, M.T., R.D. Kenney and P.K. Hamilton. 2000. Right whales (Eubalaena glacialis) on Jeffreys Ledge: a habitat of unrecognized importance? Marine Mammal Science 16:326-337.

Winn, H.E., C.A. Price and P.W. Sorensen. 1986. The distributional biology of the right whale (Eubalaena glacialis) in the western North Atlantic. Report of the International Whaling Commission (Special Issue) 10:129-138. 


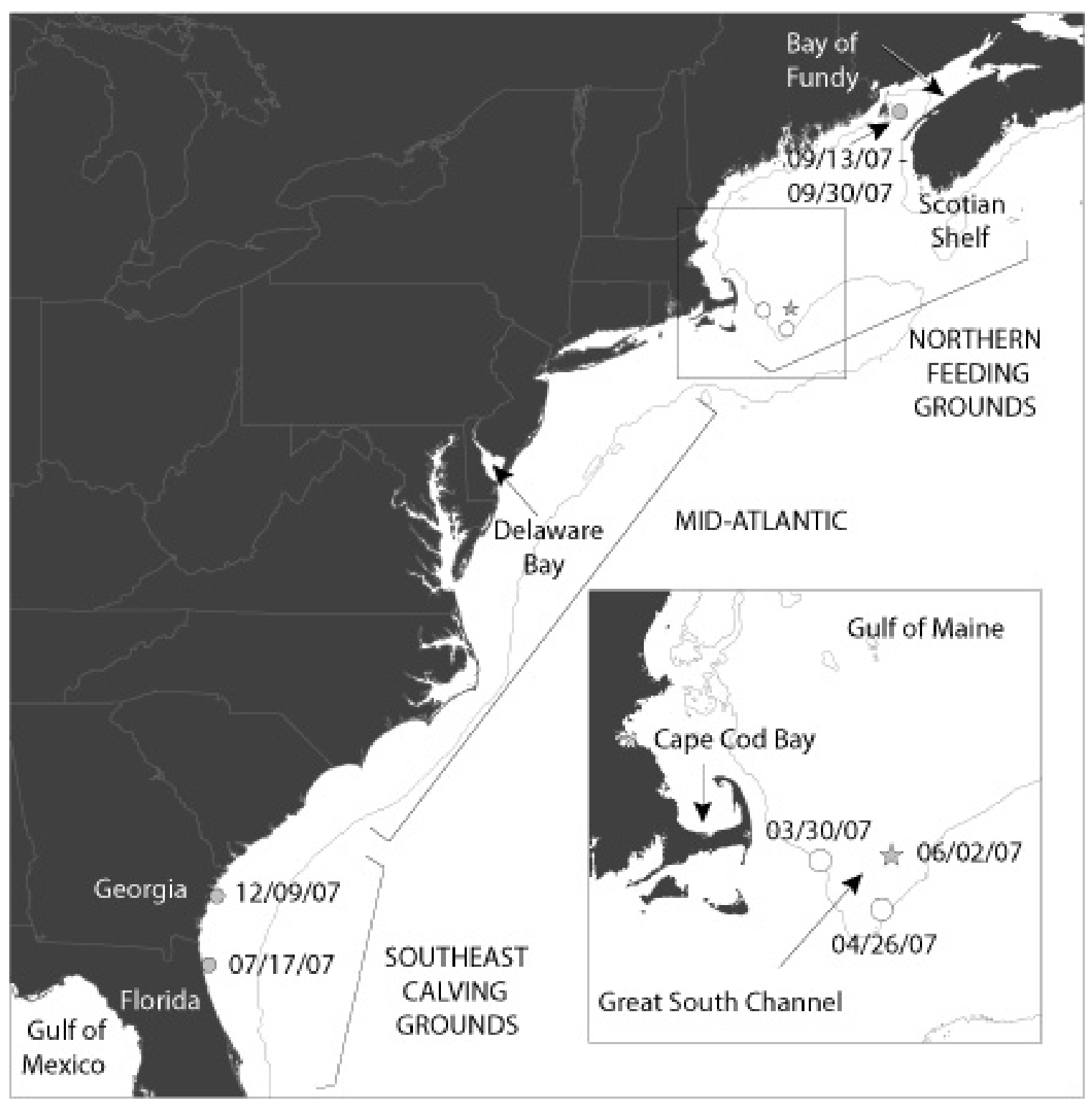

FIGURE 1 

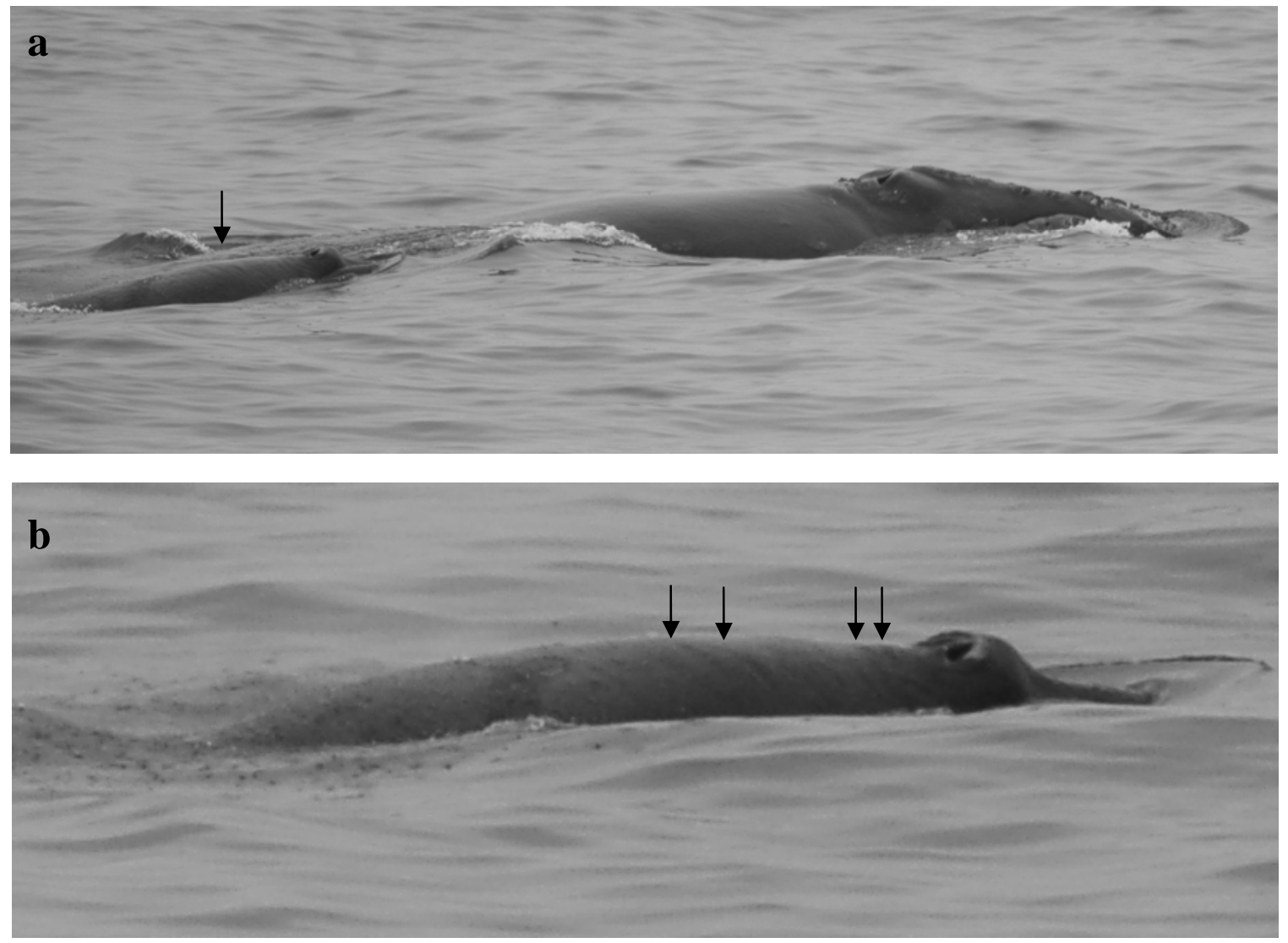

FIGURE 2 


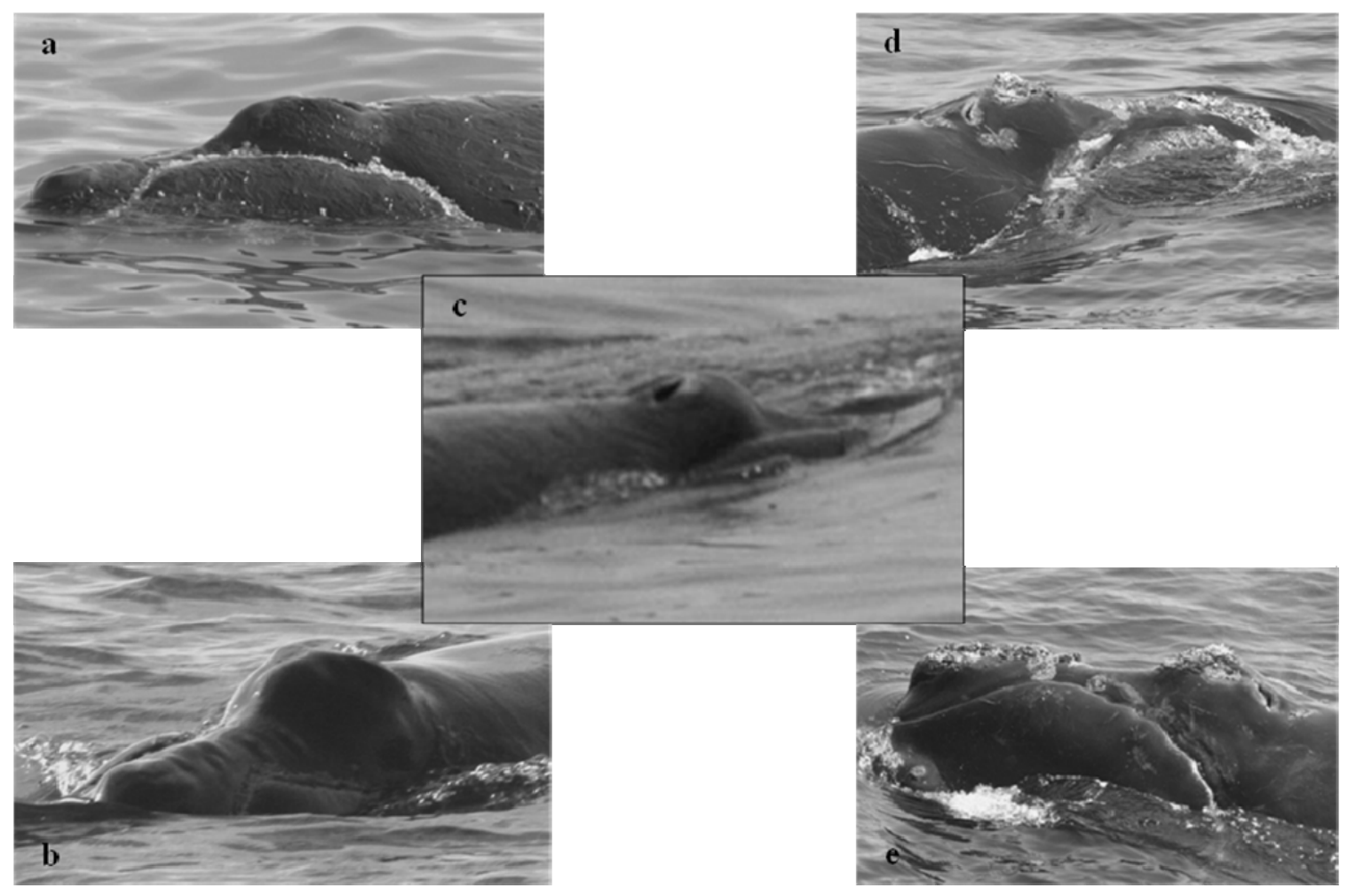

FIGURE 3 

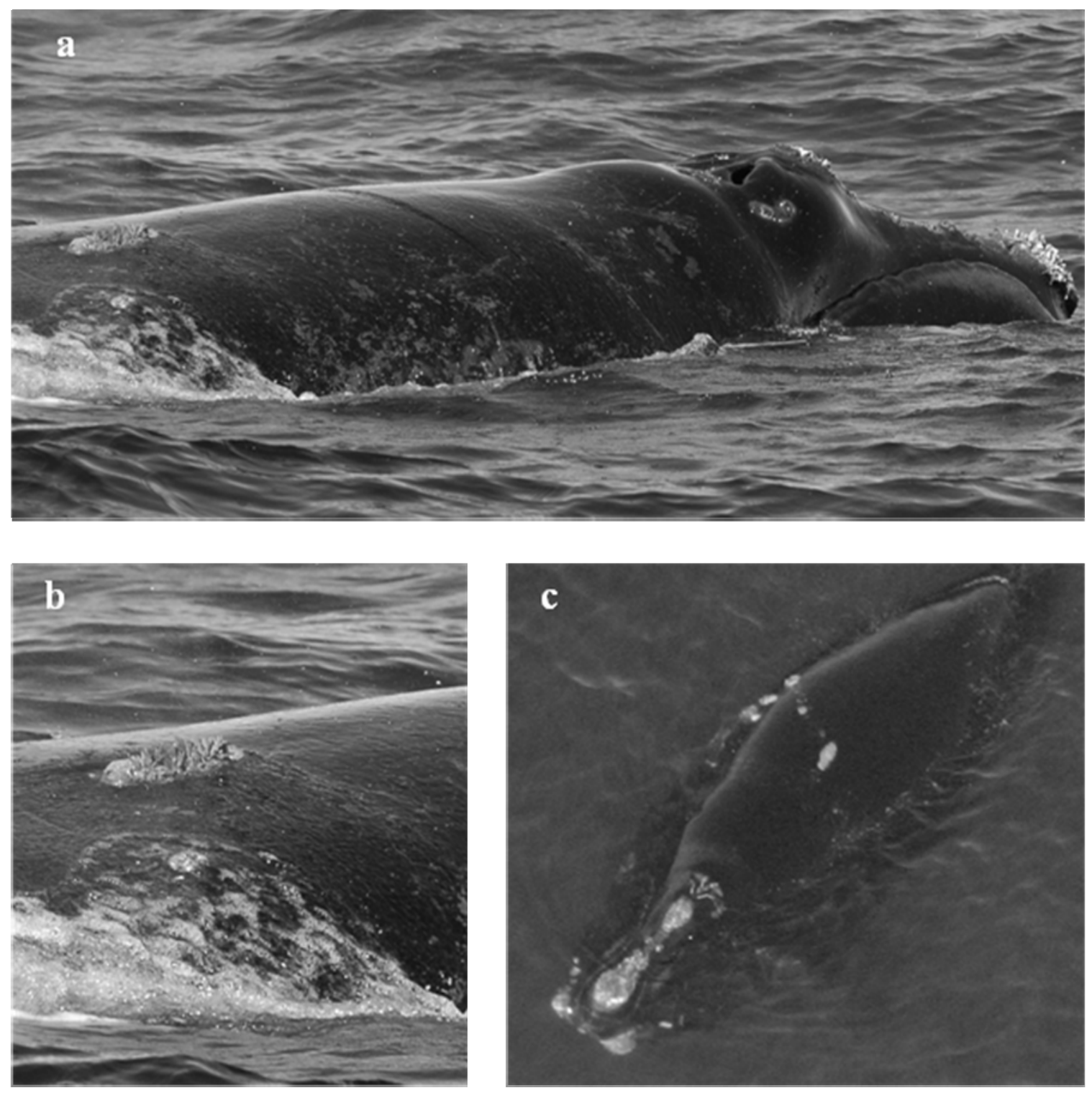

FIGURE 4 
TABLE 1

\begin{tabular}{|c|c|c|c|c|c|}
\hline Year & Total born & Only seen in NE & Calf's first sighting date & Calf ID & Calf notes (shaded are consistent with northern birth) \\
\hline \multirow{3}{*}{1994} & \multirow{3}{*}{9} & \multirow{3}{*}{3} & Late September & 2479 & Calf of 1179- normal head size and callosity growth \\
\hline & & & Late March & 2427 & Calf of 1127- moderate head size, good callosity growth \\
\hline & & & Mid April & 2413 & Calf of 1013- small head size but good callosity growth \\
\hline 1995 & 7 & & & & \\
\hline 1996 & 21 & & & & One calf seen in South Carolina and never in SEUS \\
\hline 1997 & 19 & & Early October & NA & Calf of 1412- normal head size and callosity growth \\
\hline 1998 & 5 & & & & \\
\hline 1999 & 4 & 1 & Late May & 2940 & Calf of 2210- large calf, good callosity growth \\
\hline 2000 & 1 & & & & \\
\hline 2001 & 31 & 1 & Early May & 3145 & Calf of 2145- small head size, little callosity \\
\hline 2002 & 21 & & & & One calf seen in South Carolina and never in SEUS \\
\hline 2003 & 19 & 1 & Early July & 3308 & Calf of 1608- moderate head size, good callosity growth \\
\hline 2004 & 16 & 1 & Late April & 3420 & Calf of 2460- moderate head size and callosity growth \\
\hline 2005 & 28 & & & & \\
\hline 2006 & 19 & & & & \\
\hline \multirow{4}{*}{2007} & \multirow{4}{*}{22} & \multirow{4}{*}{3} & Late April & NA & Calf of 1814- callosity visible \\
\hline & & & Early June & 3760 & Calf of 2360- very small calf, small head size, no callosity \\
\hline & & & Early July & NA & Calf of 2912- small head size, callosity visible \\
\hline & & & & & One calf seen in Virginia and never in SEUS \\
\hline
\end{tabular}



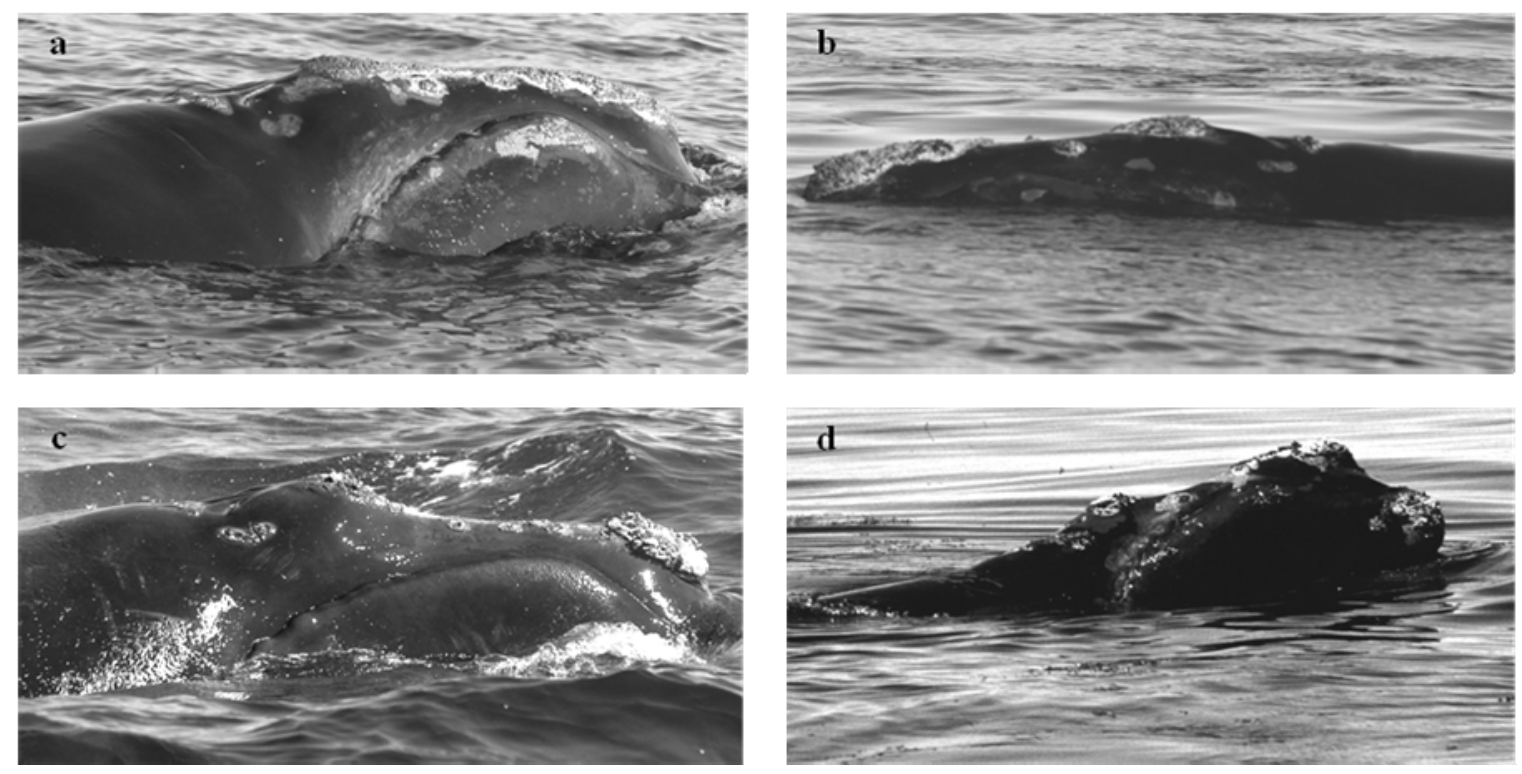

FIGURE 5 
Figure 1: Map of the eastern coast of the United States with the 2007 sightings of Eg \#2360. On 03/30/07 and 04/26/07, Eg \#2360 was seen without a calf (open symbols). All other sightings were with her 2007 calf, Eg \#3760 (shaded symbols). Our sighting on 06/02/07 is represented here with a star.

Figure 2: (a) Eg \#2360 with calf on 2 June 2007 in the Great South Channel $\left(41.60^{\circ} \mathrm{N}\right.$, $\left.68.79^{\circ} \mathrm{W}\right)$. The arrow indicates the calf. (b) Close-up of calf (Eg \#3760) showing lack of callosity growth and prominent dip in rostrum forward of the blowholes. The arrows indicate the grooves seen on the back, which may potentially be fetal folds (Photo credits: (a) \& (b) - Ingrid Biedron / Cornell Lab of Ornithology).

Figure 3: Photographs of Eg \#3760 from the 2 June 2007 sighting were compared to both calves less than 2 weeks old (photographed in the southeastern U.S. calving grounds) and also to calves 5-6 months old in the Great South Channel (the expected age of calves in this region). (a) The 2007 calf of Eg \#2614 was 12-17 days old at the time of this photograph. The first callosity tissue is seen here on the left chin (under the waterline) and cyamids are aggregating on the left lip margin of this calf. (b) The 2008 calf of Eg \#1408 was less than 10 days old at the time of this photograph. There are no callosity growths or cyamid coverage on this young calf. (c) A close-up of the head of Eg \#3760 from the 2 June 2007 sighting. The right lip margin of this animal is clearly visible in this photograph with no callosity tissue or cyamid coverage. (d) The 2005 calf of Eg \#1970 and (e) the 2005 calf of Eg \#1310 are both 5-6 months old at the time of these photographs and have much larger heads and more callosity tissue and cyamid coverage 
than the younger calves in this figure (Photo credits: (a), (b) - Clay George / Georgia Department of Natural Resources, (c) - Ingrid Biedron / Cornell Lab of Ornithology, (d), (e) - New England Aquarium).

Figure 4: The callosity-like growths on the back and right flank of Eg \#3760. (a) Eg \#3760 on 09/30/07 in the Bay of Fundy. (b) Close-up of one growth patch. (c) An aerial shot of Eg \#3760 on 12/09/07 which shows the pattern of these growths along the animals back and right flank (Photo credits: (a), (b) - Monica Zani / New England Aquarium, (c) - Clay George / Wildlife Trust and Georgia Department of Natural Resources).

Table 1: The number of calves seen in the northeastern U.S. during the spring and summer that were not seen on the southeastern U.S. calving grounds in the winter of that year. This table includes all data from when aerial survey effort started in the southeastern U.S. in 1994 to present. Shaded rows represent calves which looked younger than the baseline photographs and therefore may be calves born outside of the southeastern U.S. calving grounds.

Figure 5: Comparison of known-age calves and Eg \#3760 photographed in the Bay of Fundy during the late summer. (a) Eg \#3522 (2005 calf of Eg \#1622) and (b) Eg \# 3503 (2005 calf of Eg \#1703) were two of the calves used as a baseline approximation of head size, callosity formation, and orange cyamid coverage for 8-9 month old calves. (c) Eg \#3760 (2007 calf of Eg \#2360) and (d) Eg \#3145 (2001 calf of Eg \#1245) both have 
smaller less developed heads, less cyamid coverage, and less callosity formation than the baseline calves (Photo credits: (a), (b) - Philip Hamilton / New England Aquarium, (c) Marilyn Marx / New England Aquarium), (d) New England Aquarium. 